\title{
FPGA Based Symmetrical Multi Level Inverter with Reduced Gate Driver Circuits
}

\author{
G. Durga Prasad ${ }^{1}$, V. Jegathesan ${ }^{2}$ \\ ${ }^{1}$ Department of EEE, Shri Vishnu Engineering College for Women, Bhimavaram, A.P, India \\ ${ }^{2}$ Department of Electrical and Electronics Engineering, Karunya University, Coimbator, India
}

\section{Article Info \\ Article history: \\ Received Dec 17, 2016 \\ Revised Feb 11, 2017 \\ Accepted Feb 21, 2017}

\section{Keywords:}

Field programmble gate array Level genereatio part Multi level inverter Reversing voltage part Total harmonic distortion

\begin{abstract}
Multilevel converters tender advantages in terms of the output waveform quality due to the increased number of levels used in the output voltage modulation and have been widely accepted for high-power high-voltage applications. This paper introduces topology in multilevel dc link inverter (MLDCLI), which can significantly reduce the switch count and improve the performance. The preferred topology provides a dc voltage with the shape of a staircase approximating the rectified shape of a commanded sinusoidal wave, to the bridge inverter, which in turn gives the required alternating waveform. This topology requires fewer components compared to traditional Multi level Inverters (MLI).Therefore, the overall cost and complexity are significantly reduced particularly for higher output voltage levels. Finally, Matlab/Simulink and XILINX are used as a simulation and compiler architecture of control circuit embedded in FPGA. Simulation and experimental results for fifteen-level inverter are presented for validation
\end{abstract}

Copyright () 2017 Institute of Advanced Engineering and Science. All rights reserved.

\section{Corresponding Author:}

G. Durga Prasad,

Department of Electrical and Electronics Engineering,

Shri Vishnu Engineering College for Women,

Bhimavaram, Andhra Pradesh, India.

Email: durgaprasad_garapati@svecw.edu.in

\section{INTRODUCTION}

Multi level converter technologies are receiving increased attention recently, especially for use in high power applications [1-2]. This increased attention is probably due to the fact that the output waveforms are much improved over those of the two-level converter technologies, and that the voltage rating of the converter is increased due to the series connection of the devices. Figure 1 shows one way to classify multilevel converters, similar to the classification by Lai and Peng [3].

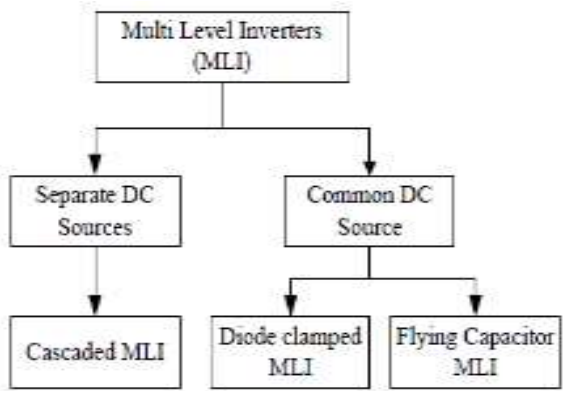

Figure 1. Types of basic multi level inverters 
The general concept in MLI's involves utilizing a higher number of active semiconductor switches to perform the power conversion in small voltage steps. There are several advantages to this approach when compared with the conventional power conversion approach. The smaller voltage steps lead to the production of higher power quality waveforms and also reduce voltage $(\mathrm{dv} / \mathrm{dt})$ stress on the load and the electromagnetic compatibility concerns [4].

In recent years, there has been a substantial increase in interest to multilevel power conversion. Recent research has involved the introduction of novel converter topologies and unique modulation strategies. Some applications for these new converters include industrial drives [5]-[7], flexible ac transmission systems (FACTS) [8]-[10], and vehicle propulsion [11]-[12]. One area where multilevel converters are particularly suitable is that of renewable photovoltaic energy that efficiency and power quality are of great concerns for the researchers [13]. Some new approaches have been recently suggested such as the topology utilizing low-switching-frequency high-power devices. Although the topology has some modification to reduce output voltage distortion, the general disadvantage of this method is that it has significant low-order current harmonics [14]. The multilevel output is generated with a multi winding transformer. However, the design and manufacturing of a multi winding transformer are difficult and costly for high-power applications. Equal valued dc supplies are employed for preferred configuration which causes the topology into symmetrical that have flexibility to arrange the dc supplies easily to get the required output voltage levels and it is also effortless on the way to increase in the direction of any number of levels. Ebrahimi has proposed a new multilevel converter topology with reduced number of switch to obtain maximum levels at the output [15]. It is observed that the multi-levels are achieved through cascaded arrangement of cells, in which the successive addition of individual cells may bear equal blocking voltage, and the outset cell in the topology undergoes high blocking voltage that causes device failure which reduces efficiency. It is studied that topologies with assymetrical dc voltages will cause complexity in deriving the required voltages levels by adding and subtracting the available voltage sources to achieve particular level [16].

The topology in this paper is a symmetrical topology since all the values of all voltage sources are equal and consists of a multilevel output which is named as level generation part (LGP) and a single phase full-bridge (SPB) inverter which is named as reversing voltage part (RVP). This topology requires less number of components compared to conventional topologies. It is also more efficient since the inverter has a component which operates the switching power devices at line frequency. The devices in the LVP alone operate at higher frequencies; device in RVP will operate at line frequency. Therefore, there is no need for all switches to work in high frequency which leads to simpler and more reliable control of the inverter.

The successful operation of any topology will depends on the selection of proper control strategy and switching states. The gating pulses are derived by using sinusoidal pulse width (SPWM) and the advantages of PWM are given as (i) Control over output voltage magnitude, (ii) Reduction in magnitudes of unwanted harmonic voltages, (iii) Improved power factor with unity displacement factor. Lowest order harmonic elimination is possible by proper choice of the number of pulses per half cycle. In this paper multi carrier SPWM techniques are used. Three alternative carrier PWM strategies with differing phase relationships for a multilevel inverter are as follows:

a. In-phase disposition (IPD),

b. Phase opposition disposition (POD),

c. Alternative phase opposition disposition (APOD).

IPD or PD strategy is used most frequently because it produces minimum harmonic distortion compare to other PWM strategies [17]-[21]. In this paper a general method of multicarrier modulation (IPD) SPWM is utilized to drive the preferred inverter topology and can be extended to any number of voltage levels.

\section{REVERSING VOLTAGE PART MULTI LEVEL DC LINK INVERTER}

In traditional multilevel inverters, the power semiconductor switches are combined to produce a high-frequency alternating waveform. However, there is no need to utilize all the switches for generating bipolar levels. The topology in this paper is a hybrid MLI which separates the output voltage into two parts as shown in Figure 2. One part of the topology is used for generating the levels only in positive polarity. This part requires high-frequency power semiconductor switches to generate the required number of levels. And other part is called reverse voltage part and is responsible for generating alternating output voltage at line frequency, this part require low-frequency power semiconductor switches and this part will operate at line frequency. 


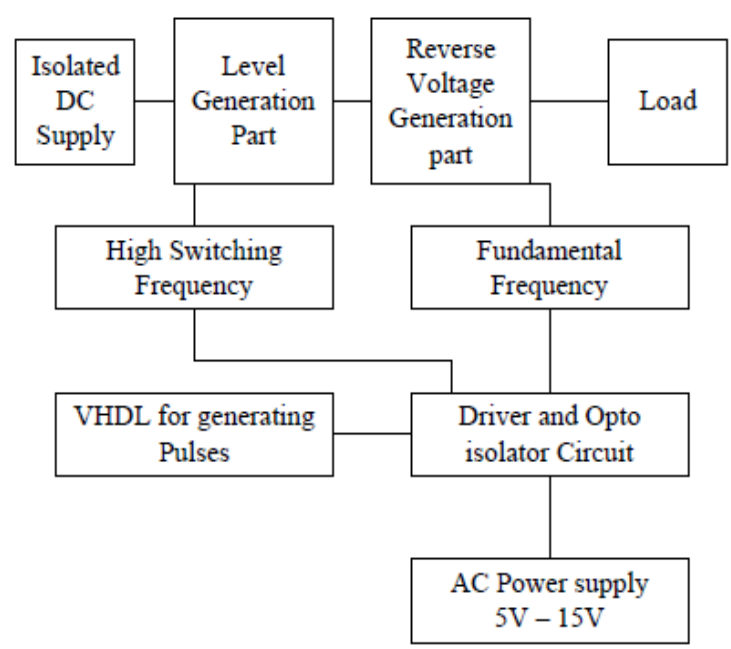

Figure 2. Block diagram of the preferred MLDCLI topology

The topology combines the high frequency and low frequency parts to generate the necessary multilevel output voltage. In order to generate a complete multilevel output, the positive levels are generated by the LGP, and then, this is fed to a SPB inverter for RVP, which will generate the required polarity for the output. The RV topology for fifteen levels is shown in Figure 3. As can be seen, it requires seven switches, six diodes and seven isolated sources. Left part of circuit is used to generate the required output levels with positive polarity and the right part of circuit is SPB inverter, decides about the polarity of the output voltage i.e. alternating waveform with required levels. It reverses the voltage direction when the voltage polarity requires to be changed for negative polarity. The preferred topology easily extends to higher voltage levels by duplicating the module as shown in Figure 3. It can also be applied for three-phase applications with the same principle. Comparison between preferred topology and conventional topologies is given in Table 1. It can be clearly seen that the preferred topology requires less number of components. So an added advantage of this topology is that it will occupy less space and produce the required output with lesser distortions. The maximum output voltage is obtained by adding the amplitude of all the DC sources connected in the circuit. Therefore the output voltage levels are derived by selection of individual DC source and by proper switching action of the power semiconductor switches.

$$
V_{\text {Output } \max }=\sum_{k=1}^{n} V_{k}
$$

The LG part provides a dc bus voltage, with the shape of a staircase that approximates the rectified waveform of the commanded sinusoidal voltage, to the RV part, which in turn alternates the voltage polarity to produce an ac voltage of a staircase shape with required levels.

The active number of switches in preferred topology

$$
=\left[\left(\frac{m-1}{2}\right)+4\right]
$$

Number of dc sources

$$
=\frac{(\mathrm{m}-1)}{2}
$$

Number of Diode 


$$
=\frac{(\mathrm{m}-3)}{2}
$$

Where, $\mathrm{m}$ is the number of levels.

Table 1. Comparison of number of components for fifteen level single phase MLI Inverters

\begin{tabular}{|c|c|c|c|c|c|c|c|c|}
\hline \multirow[b]{2}{*}{ S1.No } & \multirow{2}{*}{ MLI structure } & \multirow{2}{*}{ CHB } & \multirow{2}{*}{$\mathrm{DC}$} & \multirow{2}{*}{$\mathrm{FC}$} & \multicolumn{3}{|c|}{ MLDCLI } & \multirow{2}{*}{$\begin{array}{l}\text { Preferred } \\
\text { MLDCLI }\end{array}$} \\
\hline & & & & & $\mathrm{CHB}$ & $\mathrm{DC}$ & $\mathrm{FC}$ & \\
\hline 1 & Main switches & 28 & 28 & 28 & 24 & 18 & 18 & 11 \\
\hline 2 & Bypass diodes & 0 & 0 & 0 & 0 & 0 & 0 & 7 \\
\hline 3 & Clamping diodes & 0 & 24 & 0 & 0 & 12 & 0 & 0 \\
\hline 4 & DC Split capacitors & 0 & 6 & 6 & 0 & 6 & 6 & 0 \\
\hline \multirow[t]{2}{*}{5} & Clamping capacitors & 0 & 0 & 12 & 0 & 0 & 6 & 0 \\
\hline & Total & 35 & 59 & 47 & 25 & 37 & 31 & 18 \\
\hline
\end{tabular}

This topology uses isolated dc supplies. Therefore, it does not face voltage-balancing problems due to fixed dc voltage values, the isolated dc supplies can be replaced by renewable sources by properly designed control ciruit to avoid voltage balancing problems [22]. The topology can extend to three phase applications and shown in Figure 4, the complete three-phase inverter for fifteen levels is shown with a threephase delta connected system [23].

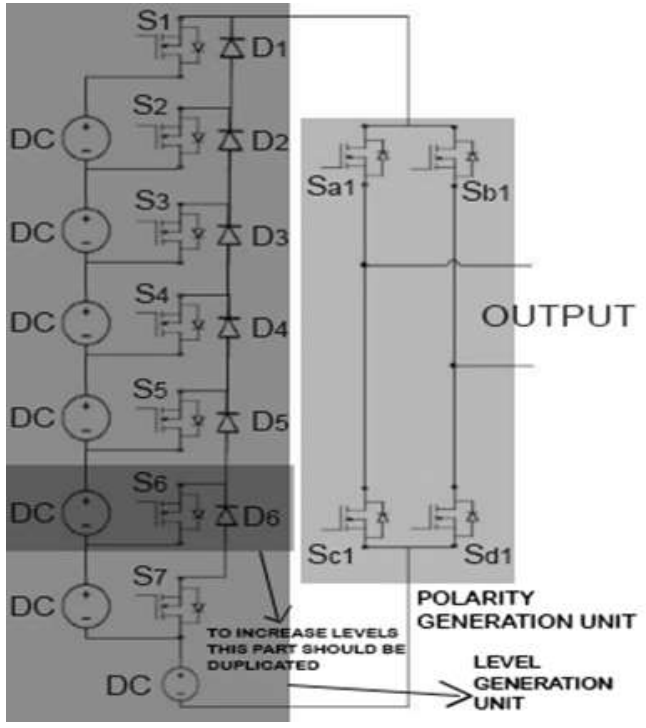

Figure 3. Schematic of preferred MLDCLI 15 level in single phase with duplicating module to increase level

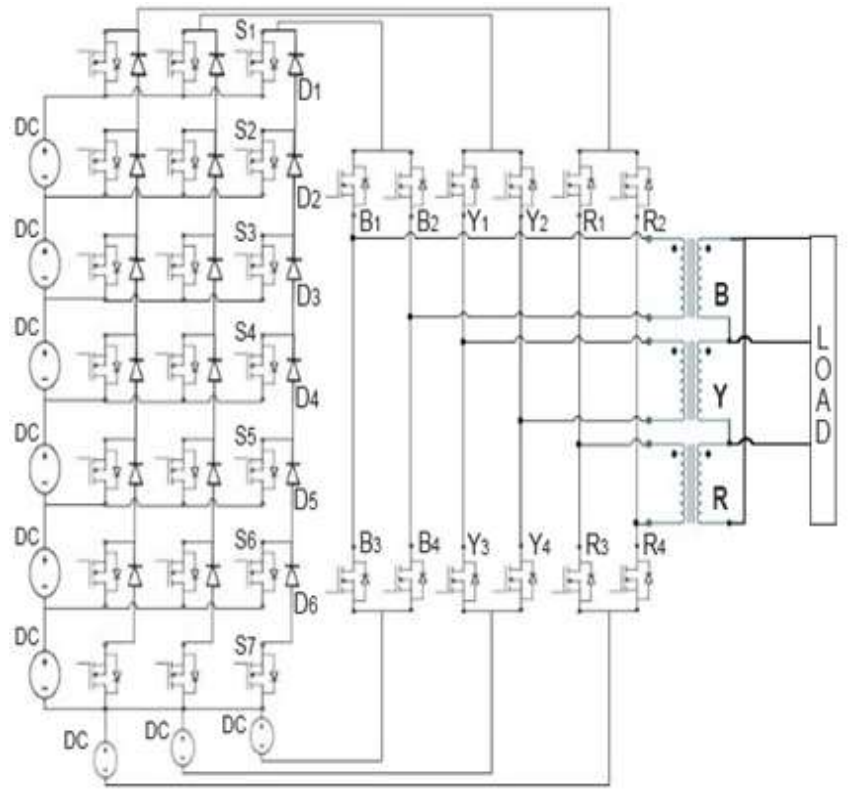

Figure 4. Schematic of a fifteen-level inverter in three phase

According to Figure 4, the multilevel positive voltage is fed to the full-bridge converter to generate its alternating waveform. Then, the $\mathrm{o} / \mathrm{p}$ of the each full bridge converter is connected to the primary of a transformer. The secondary of the transformer is delta connected and can be connected to a three-phase system. This topology requires fewer components in comparison to conventional inverters. Another advantage of this topology is that it just requires half of the conventional carriers for SPWM controller. SPWM for fifteen-level conventional converters consists of fourteen carriers, but in this topology, seven carriers are sufficient. The reason is that, according to Figure 3, the concept of generating multilevel works 
only in LG part. Therefore, it implements the multilevel inverter with a reduced number of carriers, which is a great achievement for inverter control.

The preferred topology does not need fast switches for the reverse generation part. Switching sequences in this converter are easier than its counter parts. According to its inherent advantages, it does not need to generate negative pulses for negative cycle control. Thus, there is no need for extra conditions for controlling the negative voltage. Instead the single phase full bridge converter performs this task and generates the reverse polarity. Table 2 gives detail description of the switching states of the topology for 15level inverter with both LG part and RV part.

Table 2. Switching States of the Hybrid Fifteen Level Topology

\begin{tabular}{|c|c|c|c|c|c|c|c|c|c|c|c|c|c|}
\hline \multirow{2}{*}{ Level } & \multirow{2}{*}{$\begin{array}{l}\text { Output } \\
\text { Voltage }\end{array}$} & \multicolumn{7}{|c|}{ Switch Status of the LG Part } & \multicolumn{4}{|c|}{ Switch Status of RV Part } & \multirow{2}{*}{$\begin{array}{l}\text { Fundamental } \\
\text { Cycle } \\
0-\pi\end{array}$} \\
\hline & & S7 & S6 & S5 & $\mathrm{S} 4$ & S3 & $\mathrm{S} 2$ & $\mathrm{~S} 1$ & $\mathrm{Sa}$ & $\mathrm{Sb}$ & $\mathrm{Sc}$ & $\mathrm{Sd}$ & \\
\hline 1 & 0 & 0 & 0 & 0 & 0 & 0 & 0 & 0 & 1 & 1 & 0 & 0 & \\
\hline 2 & $1 * V_{\mathrm{DC}}$ & & 0 & 0 & 0 & 0 & 0 & 0 & 1 & 1 & 0 & 0 & \\
\hline 3 & $2 * V_{\mathrm{DC}}$ & $\mathrm{X}$ & & 0 & 0 & 0 & 0 & 0 & 1 & 1 & 0 & 0 & \\
\hline 4 & $3 * V_{\mathrm{DC}}$ & $\mathrm{x}$ & $\mathrm{x}$ & & 0 & 0 & 0 & 0 & 1 & 1 & 0 & 0 & \\
\hline 5 & $4 * V_{\mathrm{DC}}$ & $\mathrm{x}$ & $\mathrm{x}$ & $\mathrm{x}$ & & 0 & 0 & 0 & 1 & 1 & 0 & 0 & \\
\hline 6 & $5^{*} \mathrm{~V}_{\mathrm{DC}}$ & $\mathrm{X}$ & $\mathrm{X}$ & $\mathrm{X}$ & $\mathrm{x}$ & & 0 & 0 & 1 & 1 & 0 & 0 & \\
\hline 7 & $6^{*} V_{D C}$ & $\mathrm{X}$ & $\mathrm{X}$ & $\mathrm{X}$ & $\mathrm{X}$ & $\mathrm{X}$ & & 0 & 1 & 1 & 0 & 0 & \\
\hline 8 & $7 * V_{D C}$ & $\mathrm{x}$ & $\mathrm{x}$ & $\mathrm{x}$ & $\mathrm{x}$ & $\mathrm{x}$ & $\mathrm{x}$ & & 1 & 1 & 0 & 0 & \\
\hline 9 & $6^{*} V_{D C}$ & $\mathrm{x}$ & $\mathrm{X}$ & $\mathrm{X}$ & $\mathrm{X}$ & $\mathrm{x}$ & & 0 & 1 & 1 & 0 & 0 & \\
\hline 10 & $5^{*} V_{\mathrm{DC}}$ & $\mathrm{X}$ & $\mathrm{X}$ & $\mathrm{X}$ & $\mathrm{X}$ & & 0 & 0 & 1 & 1 & 0 & 0 & \\
\hline 11 & $4^{*} V_{D C}$ & $\mathrm{x}$ & $\mathrm{X}$ & $\mathrm{X}$ & & 0 & 0 & 0 & 1 & 1 & 0 & 0 & \\
\hline 12 & $3^{*} \mathrm{~V}_{\mathrm{DC}}$ & $\mathrm{X}$ & $\mathrm{X}$ & & 0 & 0 & 0 & 0 & 1 & 1 & 0 & 0 & \\
\hline 13 & $2 * V_{\mathrm{DC}}$ & $\mathrm{x}$ & & 0 & 0 & 0 & 0 & 0 & 1 & 1 & 0 & 0 & \\
\hline 14 & $1 * \mathrm{~V}_{\mathrm{DC}}$ & & 0 & 0 & 0 & 0 & 0 & 0 & 1 & 1 & 0 & 0 & \\
\hline 15 & 0 & 0 & 0 & 0 & 0 & 0 & 0 & 0 & 1 & 1 & 0 & 0 & \\
\hline 1 & 0 & 0 & 0 & 0 & 0 & 0 & 0 & 0 & 0 & 0 & 1 & 1 & $\pi-2 * \pi$ \\
\hline 2 & $1 * \mathrm{~V}_{\mathrm{DC}}$ & & 0 & 0 & 0 & 0 & 0 & 0 & 0 & 0 & 1 & 1 & \\
\hline 3 & $2^{*} \mathrm{~V}_{\mathrm{DC}}$ & $\mathrm{x}$ & & 0 & 0 & 0 & 0 & 0 & 0 & 0 & 1 & 1 & \\
\hline 4 & $3^{*} \mathrm{~V}_{\mathrm{DC}}$ & $\mathrm{X}$ & $\mathrm{X}$ & & 0 & 0 & 0 & 0 & 0 & 0 & 1 & 1 & \\
\hline 5 & $4^{*} V_{D C}$ & $\mathrm{X}$ & $\mathrm{X}$ & $\mathrm{X}$ & & 0 & 0 & 0 & 0 & 0 & 1 & 1 & \\
\hline 6 & $5^{*} V_{D C}$ & $\mathrm{X}$ & $\mathrm{X}$ & $\mathrm{X}$ & $\mathrm{X}$ & & 0 & 0 & 0 & 0 & 1 & 1 & \\
\hline 7 & $6^{*} V_{\mathrm{DC}}$ & $\mathrm{x}$ & $\mathrm{X}$ & $\mathrm{X}$ & $\mathrm{X}$ & $\mathrm{x}$ & & 0 & 0 & 0 & 1 & 1 & \\
\hline 8 & $7 * V_{D C}$ & $\mathrm{X}$ & $\mathrm{X}$ & $\mathrm{X}$ & $\mathrm{X}$ & $\mathrm{X}$ & $\mathrm{X}$ & & 0 & 0 & 1 & 1 & \\
\hline 9 & $6^{*} V_{D C}$ & $\mathrm{x}$ & $\mathrm{x}$ & $\mathrm{X}$ & $\mathrm{X}$ & $\mathrm{x}$ & & 0 & 0 & 0 & 1 & 1 & \\
\hline 10 & $5^{*} V_{D C}$ & $\mathrm{X}$ & $\mathrm{X}$ & $\mathrm{X}$ & $\mathrm{X}$ & & 0 & 0 & 0 & 0 & 1 & 1 & \\
\hline 11 & $4^{*} V_{D C}$ & $\mathrm{x}$ & $\mathrm{x}$ & $\mathrm{X}$ & & 0 & 0 & 0 & 0 & 0 & 1 & 1 & \\
\hline 12 & $3 * V_{\mathrm{DC}}$ & $\mathrm{X}$ & $\mathrm{X}$ & & 0 & 0 & 0 & 0 & 0 & 0 & 1 & 1 & \\
\hline 13 & $2 * \mathrm{~V}_{\mathrm{DC}}$ & $\mathrm{x}$ & & 0 & 0 & 0 & 0 & 0 & 0 & 0 & 1 & 1 & \\
\hline 14 & $1 * V_{D C}$ & & 0 & 0 & 0 & 0 & 0 & 0 & 0 & 0 & 1 & 1 & \\
\hline 15 & 0 & 0 & 0 & 0 & 0 & 0 & 0 & 0 & 0 & 0 & 1 & 1 & \\
\hline
\end{tabular}

In order to produce fifteen levels by SPWM, seven saw-tooth waveforms for seven carriers are required and a one sinusoidal reference signal as modulating signal is required as shown in Figure. 5. 


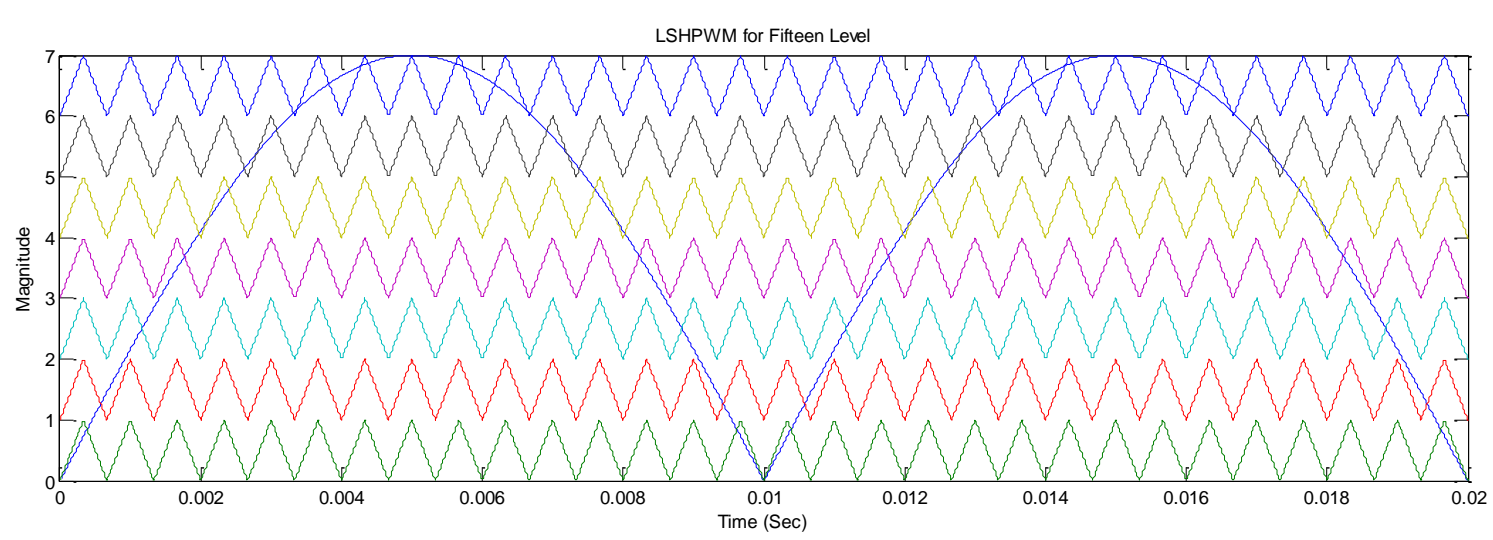

Figure 5. SPWM carrier and modulator for positive voltage level generation.

\section{FIELD PROGRAMMABLE GATE ARRAY}

Field Programmable Gate Arrays (FPGAs) are semiconductor devices that are based around a matrix of configurable logic blocks (CLBs) connected via programmable interconnects. FPGA can be programmed by different stages. Design entry is the stage of implementing a required design of the programmer in soft format on FPGA. Xilinx ISE 12.1 software is used to write a program to generate PWM pulses using VHDL (Very High Speed Integrated Chip Hardware Description Language). Once the code is written the entire code is verified for syntax. After the code is synthesized it will convert into equivalent logic gates and produces a net-list. In implementation stage, the design is used for Placing and Routing which places the logic blocks of the design into FPGA and route them together so that they occupy minimum area and meet timing requirements. Then the code is converted in to the digital bits as FPGA can understand only digital language this process is used to transfer the code from system to kit using joint test action group cable. Figure 6 shows the various steps involved in writing a program on FPGA kit [24], [25].

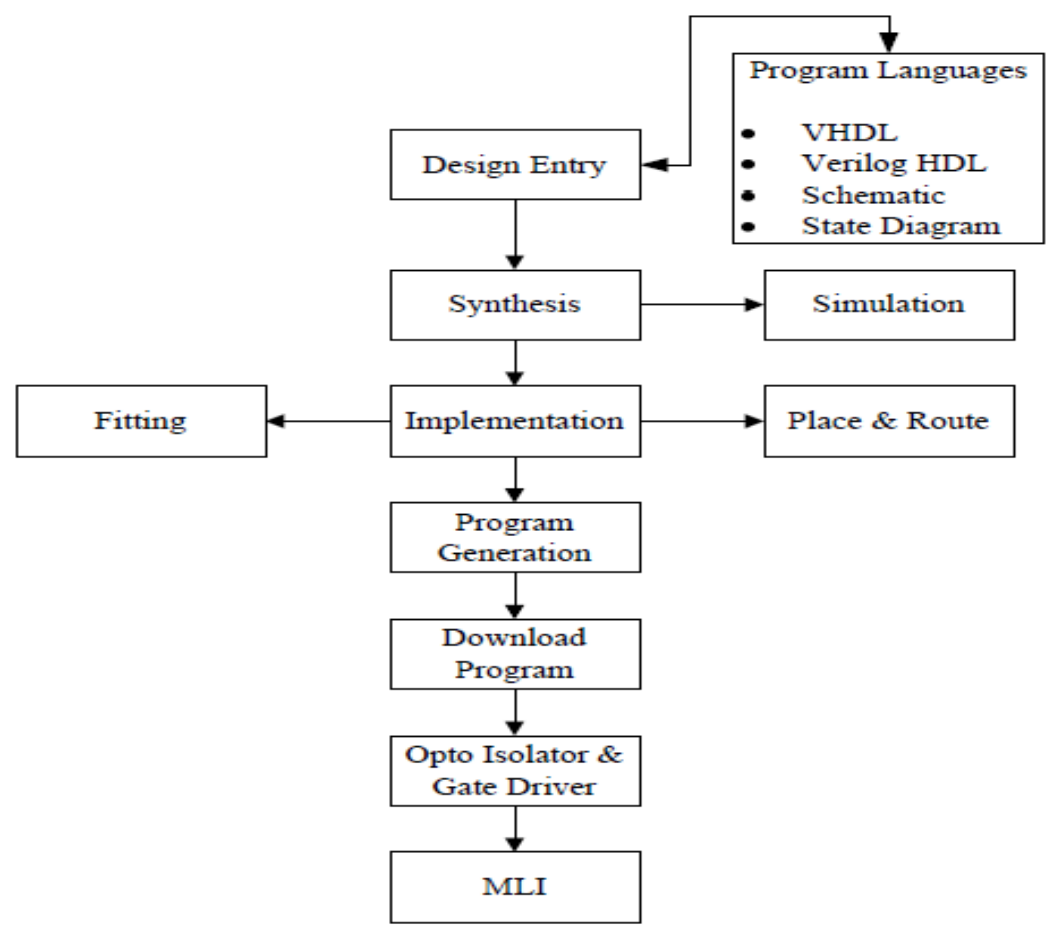

Figure 6. Stages of FPGA coding 
Advantage of the FPGA is

- Operating Speed

- Reduce in design cycle time

- $\quad$ power consumption is less

- Increase in Design flexibility and security

ModelSim simulator is used to test the design of PWM pulses of suggested MLI before transforming the pulses into hardware. Below Figure shows the flowchart of the PWM pulse generation

\section{SIMULATION RESULTS}

The topology discussed in the section 2 is tested using Matlab/Simulink software 7.9.0 (R2009b) version. The Sim-powersystems block in the Matlab/Simulink is used to test the prototype of preferred topology and the results are studied. The performances of topology have been tested with R, RL loads and extended to three phase with same principal of operation and tested for three phase induction motor by giving step torque. Figure 7 shows the simulation diagram of the topology. Figure 8 shows the output waveform of the Level Generation Part. Figures 9 to 13 shows the output waveforms for R and RL load with and without filter. Figure 14, 20, 23 shows the simulation diagram of three phase fifteen level inverter for R, RL, Induction motor loads respectively; Figure 15 and 16 shows the output waveform of voltage and current for $\mathrm{R}$ load. Figure 17 shows simulation diagram of the topology for $\mathrm{R}$ load with filter for three phase fifteen level. Figure 18 and 19 shows the output voltage and current waveforms with filter for R load with filter. Figure 21 and 22 shows output voltage and current waveforms for RL load with filter. Figure 24 shows the three phase stator current, Figure 25 shows the speed of the induction motor in rpm, and Figure 26 shows the electromagnetic torque of the induction motor. Tables 3 and 4 gives the performance analysis of the topology by varying the switching frequency with and without filter, the results clearly shows the \% THD value has been decreased almost $50 \%$ by using filter. And \% THD values falls in acceptable range by IEEE standard. Table 5 and 6 give the results of the topology by varying the modulation index and the \% THD is better when the Modulation index is one.

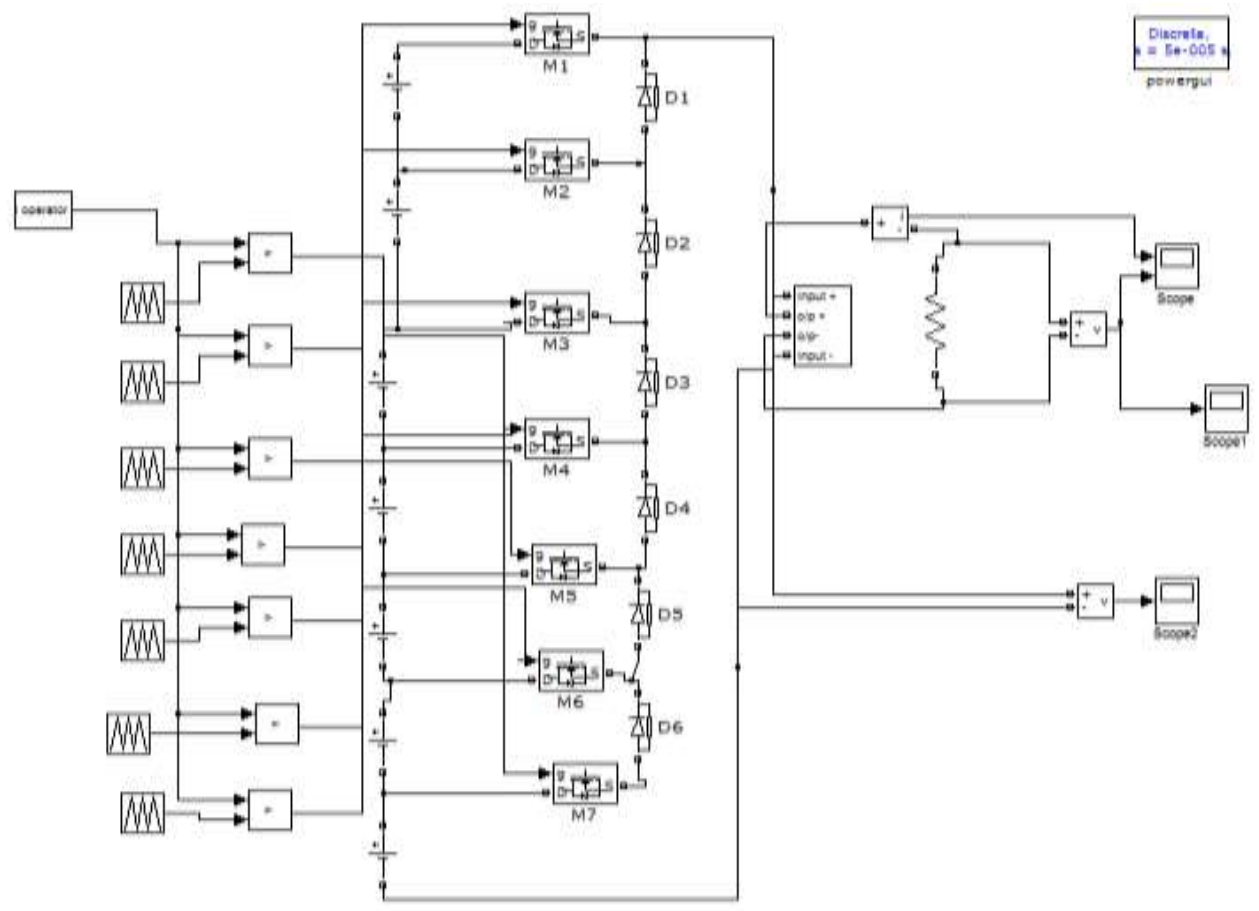

Figure 7. Simulation circuit of proposed single phase fifteen level topology 


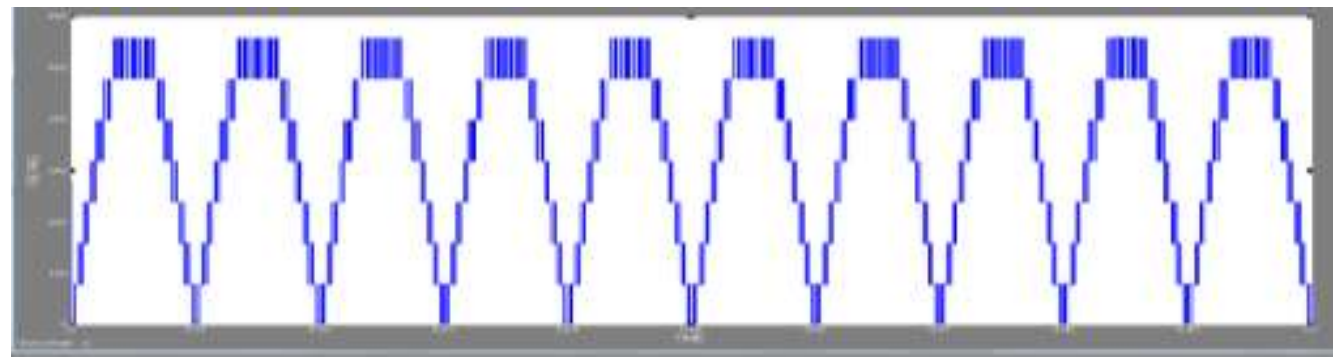

Figure 8. Output voltage waveform of level generation part

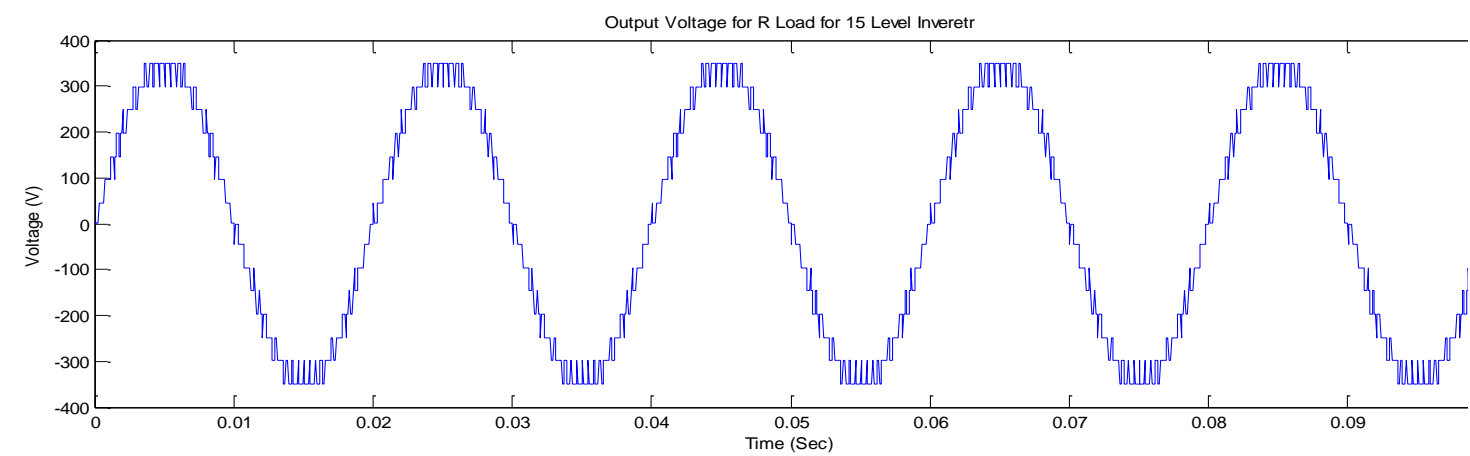

Figure 9. Output voltage waveform of reverse voltage generation part for R-Load without filter

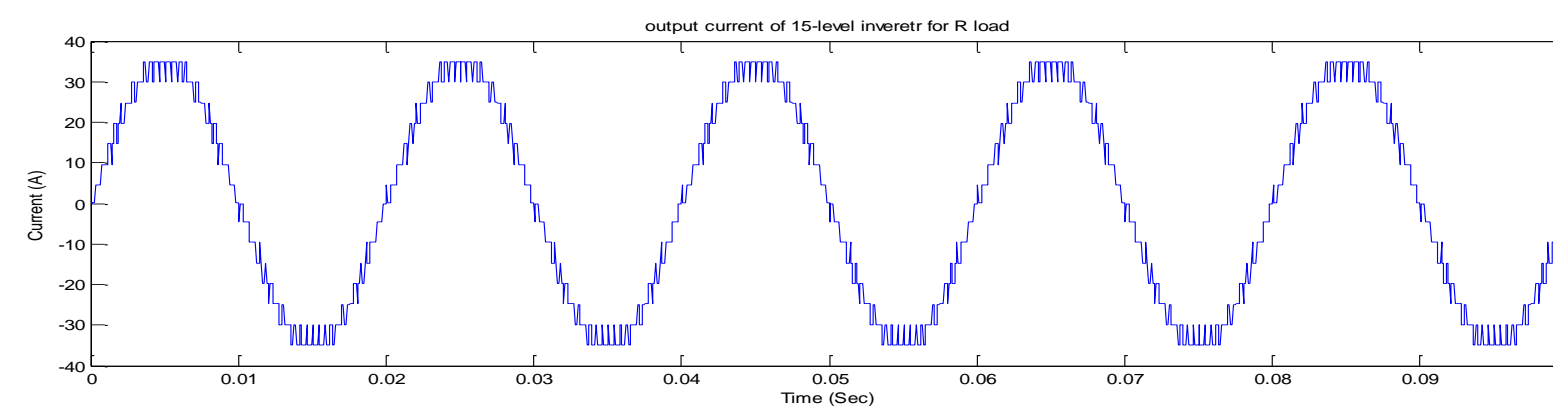

Figure 10. Output current waveform of reverse voltage generation part for R-Load without filter

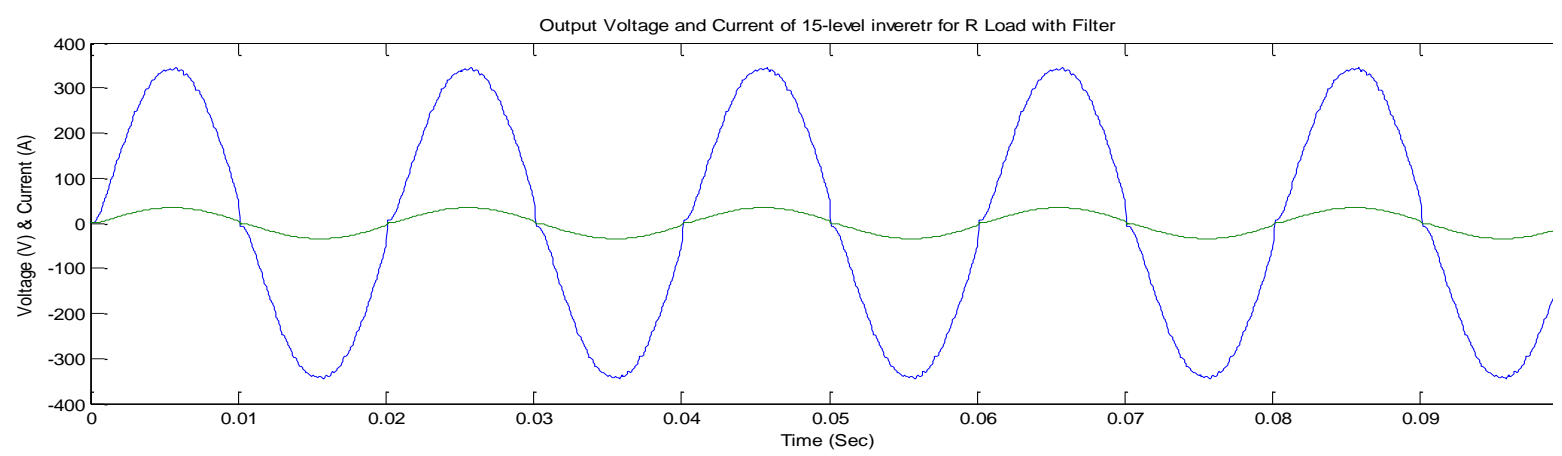

Figure 11. Output voltage and current of 15-Level Inverter for R load with filter 


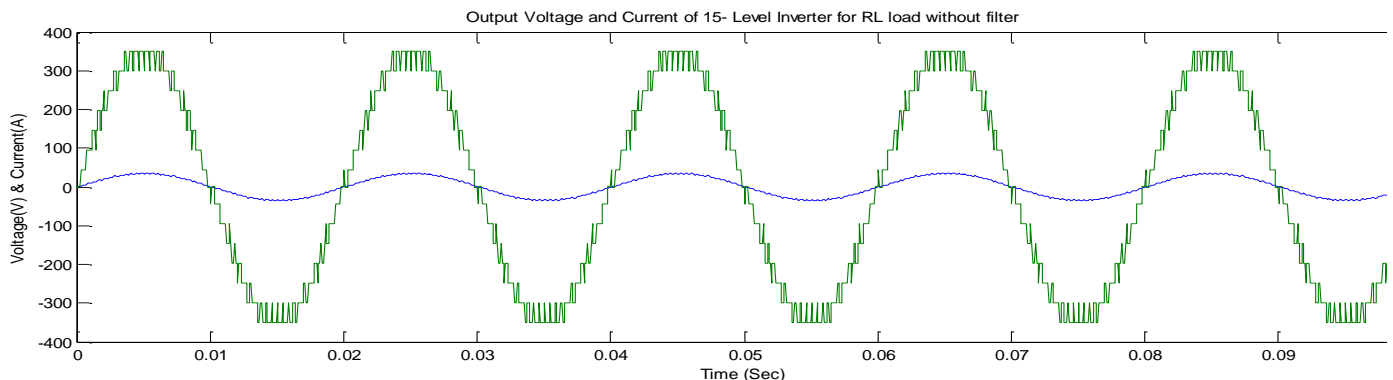

Figure 12. Output voltage and current of 15-level inverter for RL load without filter

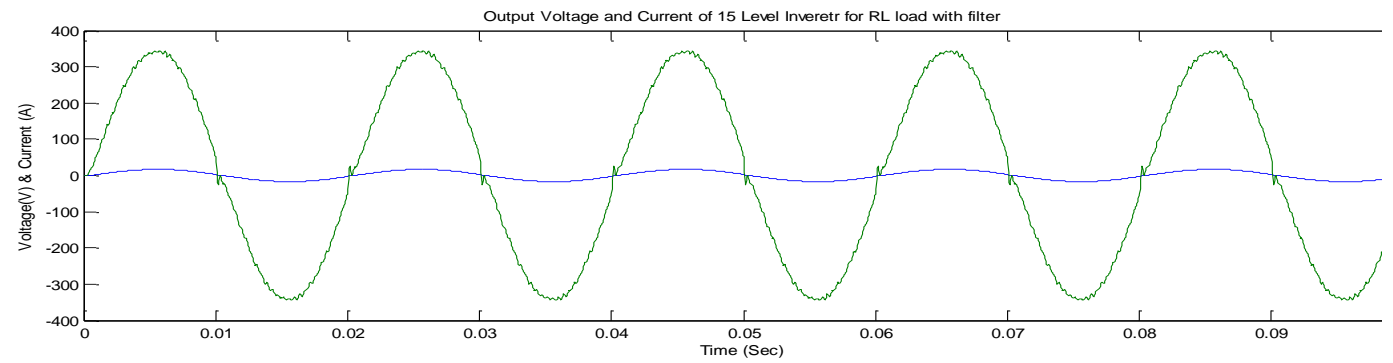

Figure 13. Output Voltage and Current of 15-Level Inverter for RL load with Filter

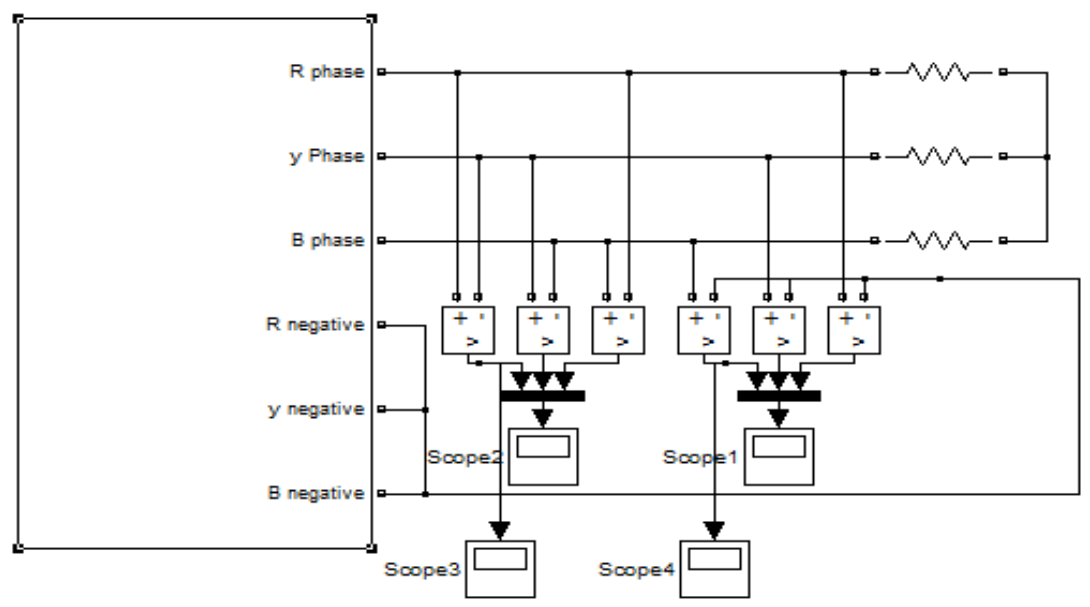

Figure 14. Subsystem of three phase Matlab/Simulink circuit for 15-level

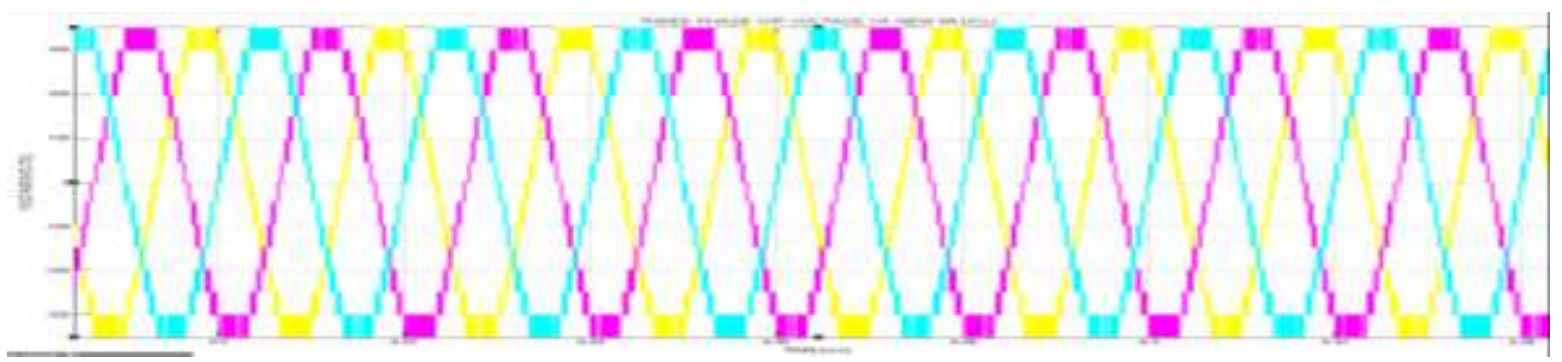

Figure 15. Three phase output voltage waveform 


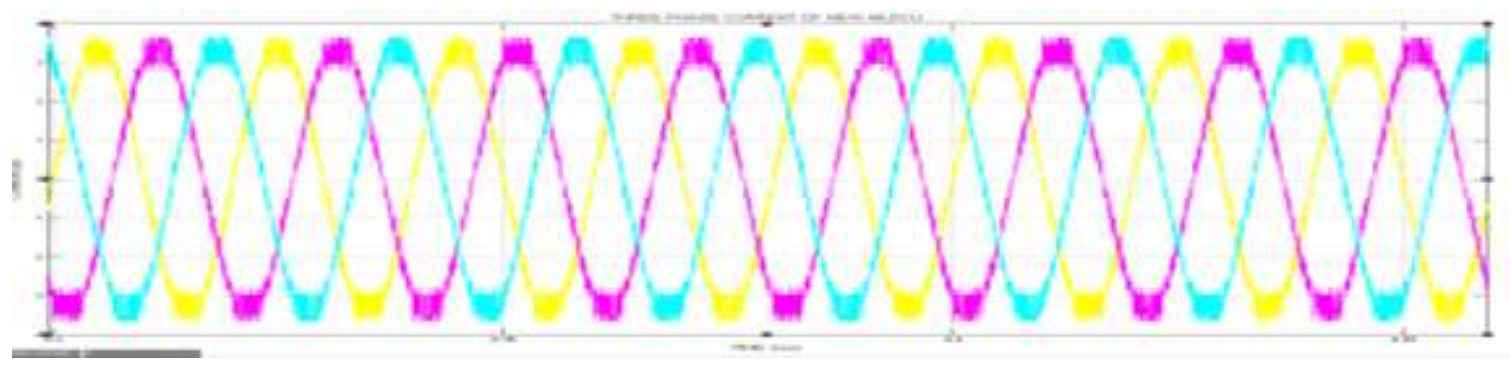

Figure 16. Current wave form of three phase circuit

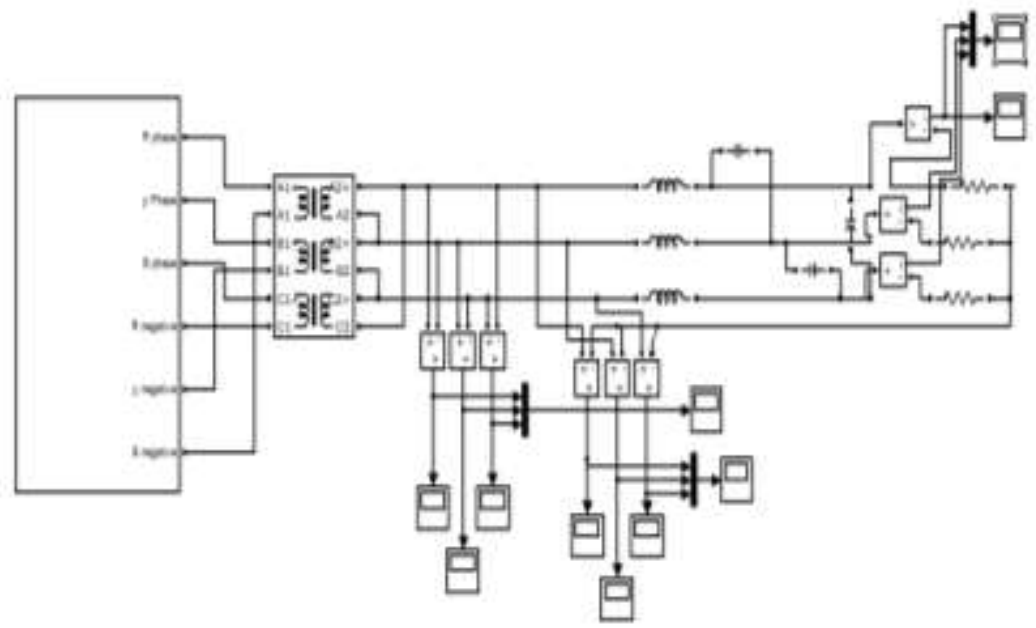

Figure 17. Three phase 15-Level Inverter for R Load with Filter

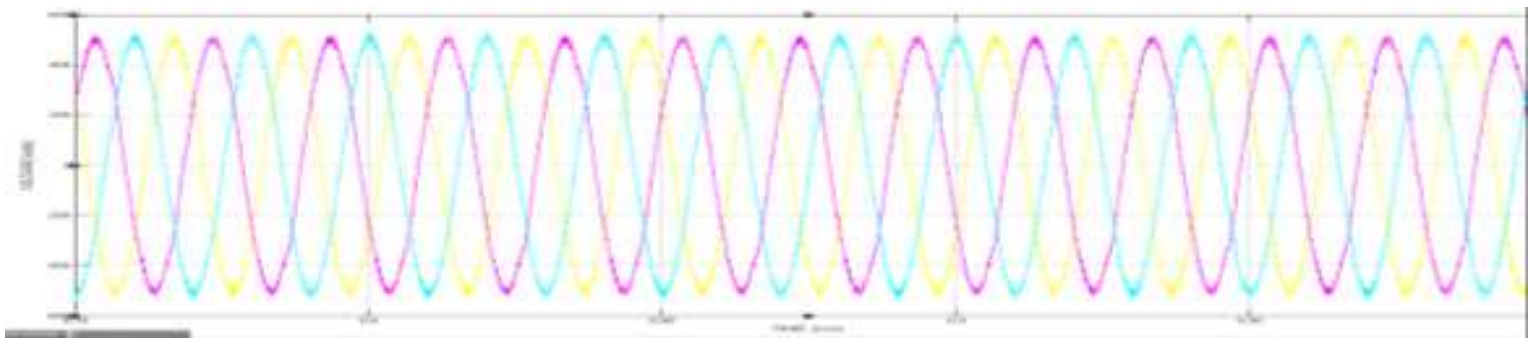

Figure 18. Three phase o/p voltage waveform for R-Load with LC filter

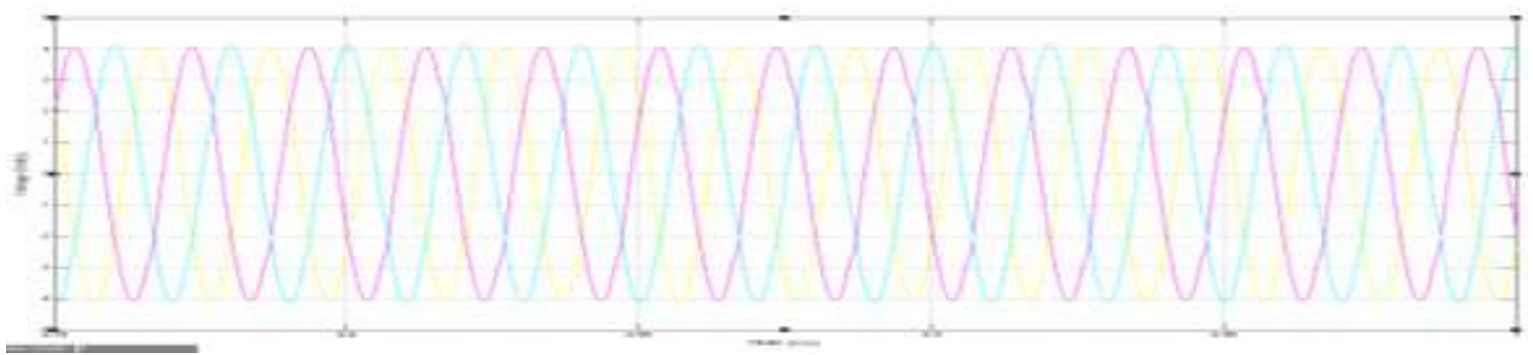

Figure 19. Three phase current waveform for R-load with filter 


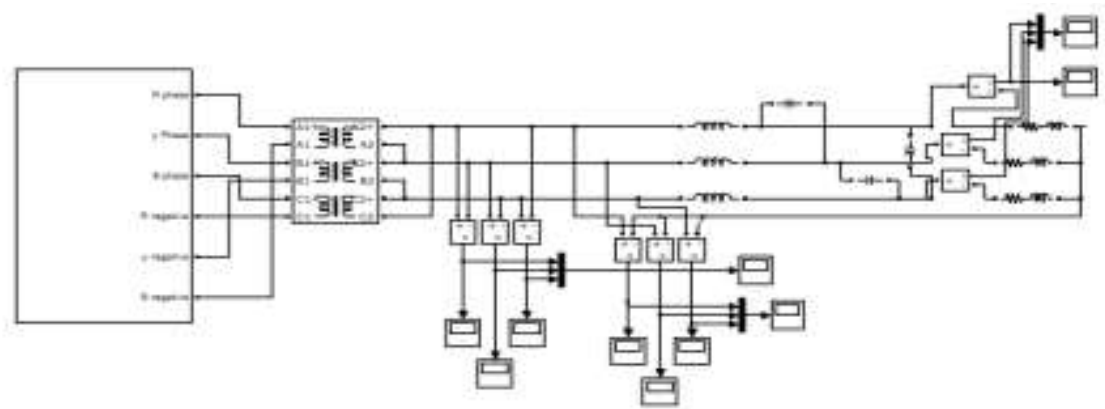

Figure 20. Simulation diagram of three phase prefeered MLDCLI for RL Load with filter

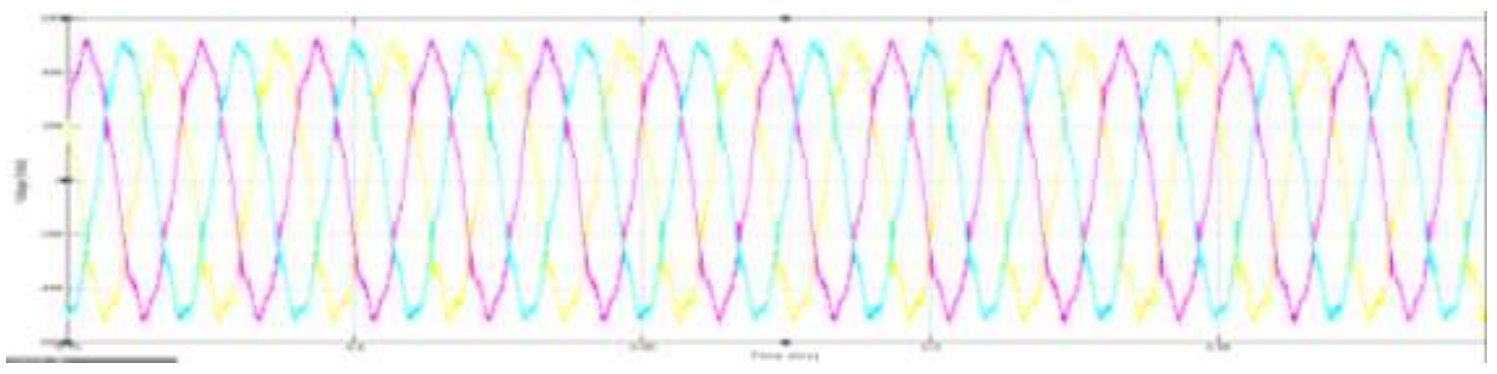

Figure 21. Three phase output phase voltage for RL-Load with filter

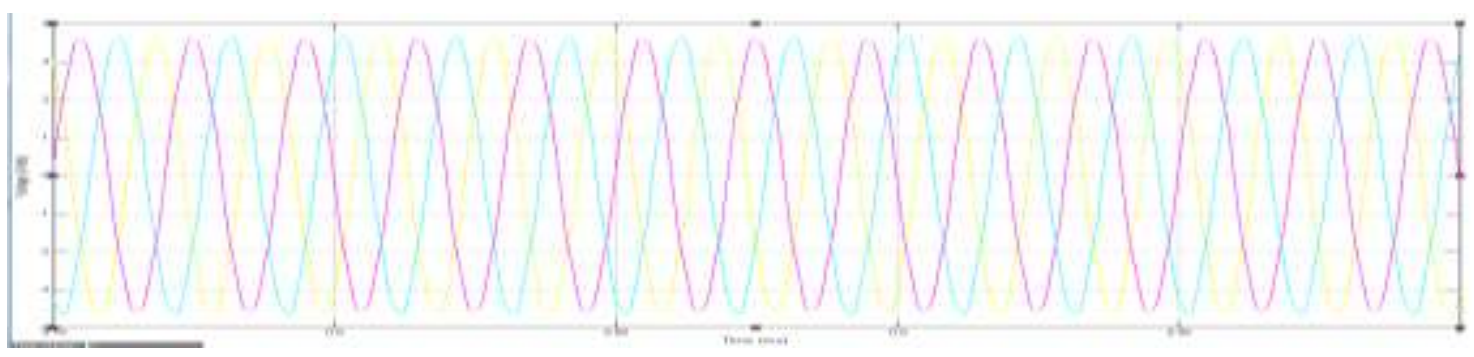

Figure 22. Output current waveform for RL-Load

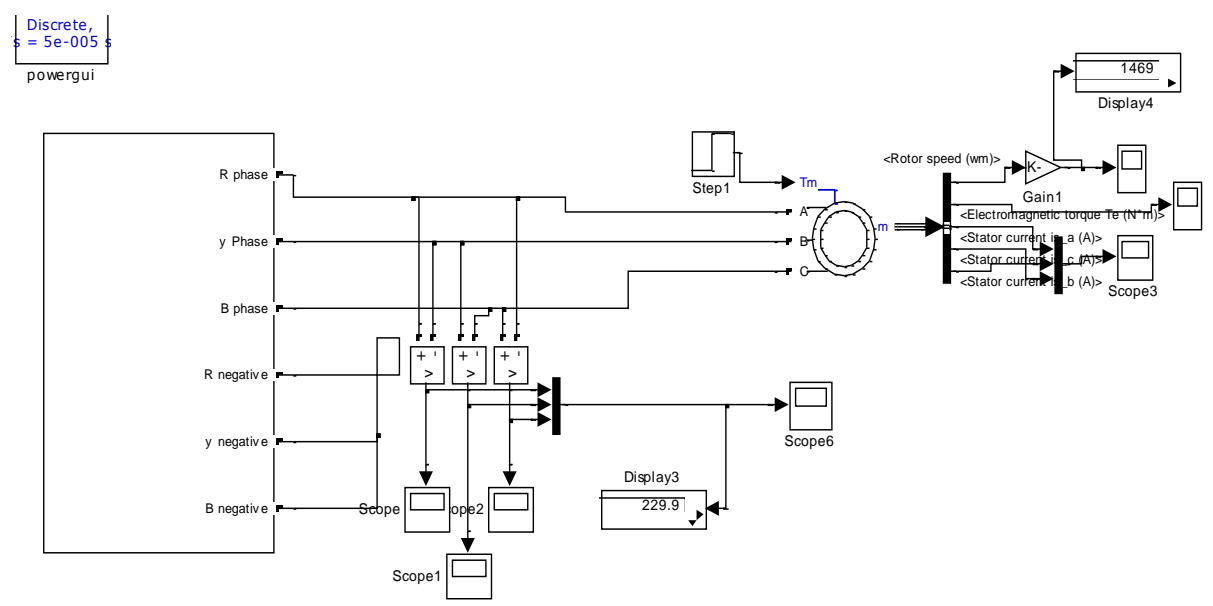

Figure 23. Simulation diagram of the preferred topolgy with Induction motor using Step torque 


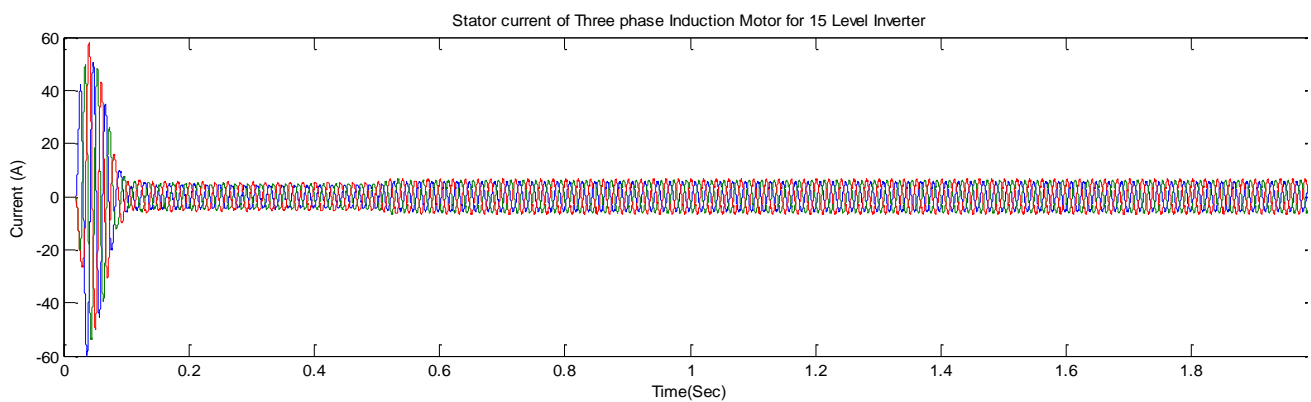

Figure 24. Stator current of three phase IM for 15-level inverter

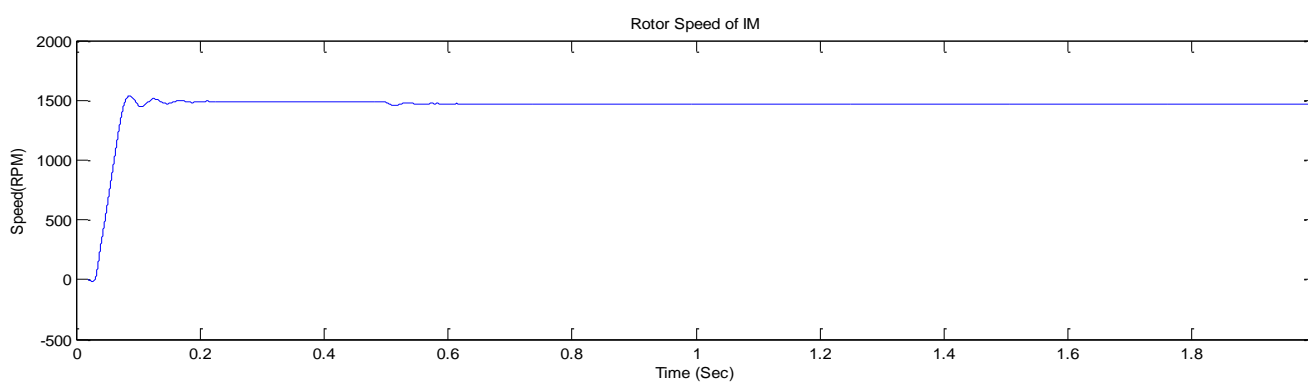

Figure 25. Rotor Speed of IM for 15-level inverter

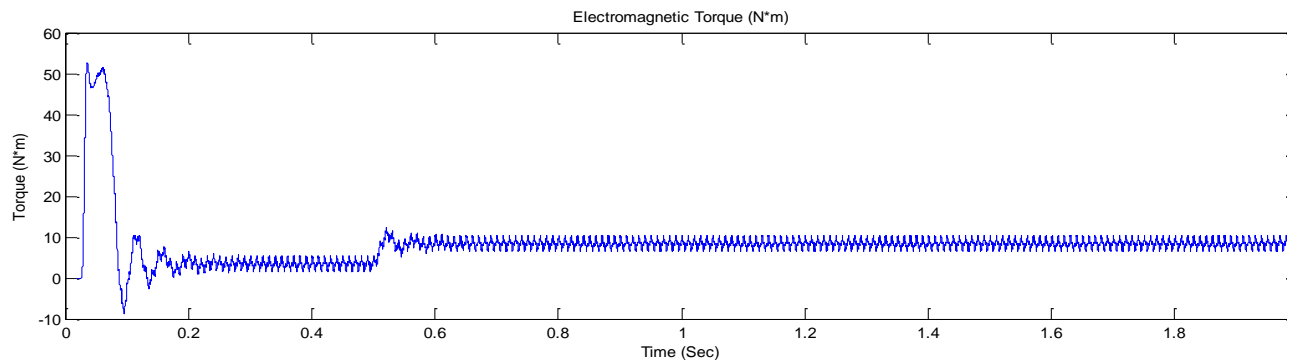

Figure 26. Electromagnetic torque of IM for 15-level inverter

Table 3. Result Analysis of Preferred MLDCLI with Filter

\begin{tabular}{ccccccc}
\hline $\begin{array}{c}\text { Switching } \\
\text { Frequency }\end{array}$ & V_peak & V_rms & THD\% & I_peak & I_rms & THD\% \\
\hline 2500 & 500.7 & 354.1 & 2.62 & 4.061 & 2.871 & 1.48 \\
3000 & 501.7 & 354.8 & 2.79 & 4.069 & 2.877 & 2.33 \\
3500 & 499.3 & 353.1 & 2.78 & 4.049 & 2.863 & 2.05 \\
4000 & 502.6 & 355.4 & 2.63 & 4.076 & 2.882 & 2.02 \\
4500 & 501.3 & 354.5 & 2.66 & 4.065 & 2.875 & 1.99 \\
5000 & 498 & 352.2 & 3.07 & 4.039 & 2.856 & 1.90 \\
\hline
\end{tabular}

Table 4. Result Analysis of Preferred MLDCLI without Filter

\begin{tabular}{ccccccc}
\hline $\begin{array}{c}\text { Switching } \\
\text { Frequency }\end{array}$ & V_peak & Ph_rms & THD\% & I_peak & I_rms & THD\% \\
\hline 2500 & 344.9 & 243.9 & 4.62 & 3.458 & 2.445 & 4.45 \\
3000 & 345.7 & 244.5 & 4.27 & 3.439 & 2.432 & 4.31 \\
3500 & 346.5 & 245 & 4.45 & 3.452 & 2.441 & 4.47 \\
4000 & 348.4 & 246.4 & 4.69 & 3.471 & 2.454 & 4.72 \\
4500 & 344.3 & 243.4 & 5.09 & 3.449 & 2.439 & 5.01 \\
5000 & 344.3 & 243.4 & 5.12 & 3.432 & 2.427 & 5.33 \\
\hline
\end{tabular}


Table 5. THD\% Varying MI

\begin{tabular}{ccc}
\hline MI & THD\% of V_phase & THD\% of Current \\
\hline 1 & 4.01 & 4.11 \\
0.8 & 4.35 & 4.37 \\
0.6 & 4.84 & 4.80 \\
0.4 & 5.10 & 5.75 \\
\hline
\end{tabular}

Table 6. \%THD Varying MI Using Filter

\begin{tabular}{|c|c|c|}
\hline MI & THD\% of V_phase & THD\% O/P Current \\
\hline 1 & 2.62 & 1.48 \\
\hline 0.8 & 3.70 & 2.22 \\
\hline 0.6 & 5.31 & 2.67 \\
\hline 0.4 & 8.03 & 2.98 \\
\hline
\end{tabular}

The performance of the preferred topology is compared with the traditional Cascaded H-Bridge (CHB) Inverter by varying the Modulation Index and it is observed that the \% THD value is less in preferred topology than traditional CHB same is shown in Table 7.

Table 7. THD\% Comparision of Prefered Topology with Traditional CHB inverter by Varying MI

\begin{tabular}{llllll}
\hline MI & $\begin{array}{l}\text { THD\% } \\
\text { topology }\end{array}$ & of & preferred & $\begin{array}{l}\text { THD\% of traditional } \\
\text { Inverter }\end{array}$ & \\
\hline 1 & 4.01 & & 9.03 & \\
0.8 & 4.35 & & 10.41 & \\
0.6 & 4.84 & & 10.83 & \\
0.4 & 5.10 & & 12.57 & \\
\hline
\end{tabular}

Table 8 shows the comparision of $\%$ THD between preferred topology and the topology discussed in [16] and the \% THD level is better than topology in [16].

Table 8. THD\% Comparision of Prefered Topology with Topology in [16] Using Various PWM Techniques

\begin{tabular}{ccc}
\hline PWM Technique & THD\% of preferred topology & THD\% of topology [16] \\
\hline PD or IPD PWM & 4.01 & 5.67 \\
PODPWM & 4.39 & 5.93 \\
APODPWM & 5.17 & 6.15 \\
\hline
\end{tabular}

\section{EXPERIMENTAL RESULTS}

The simulation circuit discussed in section 4 is carried for hardware implementation and single phase fifteen level inverter of the preferred topology is tested for R Load and validated. SPARTAN-3A DSP from the FPGA family is considered as pulse generation module and the driving pulses as required patterns are developed using VHDL. Further, the generated pulses are diagnosed using ModelSim software. The experimental procedures are executed and the measurements are carried out with a scale division of $5 \mathrm{~A} / \mathrm{div} \&$ 15 Volt/div. Figure 27 shows the hardware implementation of the topology and Figure 28 show the flowchart for gate pulse generation in LG part, Figure 29 represents the output waveform of level generation unit having only positive polarity that is obtain experimentally with modulation index (MI) $=1$ and switching frequency $=2 \mathrm{KHz}$ and Figure 30 and 31 shows the output voltage and current without and with filter respectively. Table 9 , shows the $\%$ THD variation by varying MI and switching frequency 


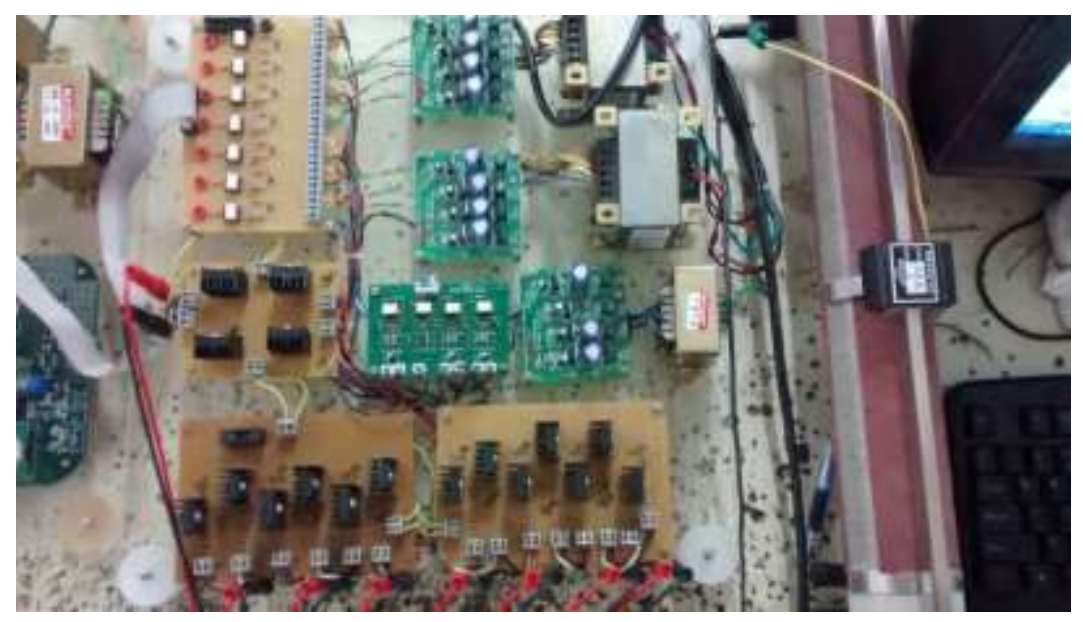

Figure 27. Experimental circuit of 15 level inverter

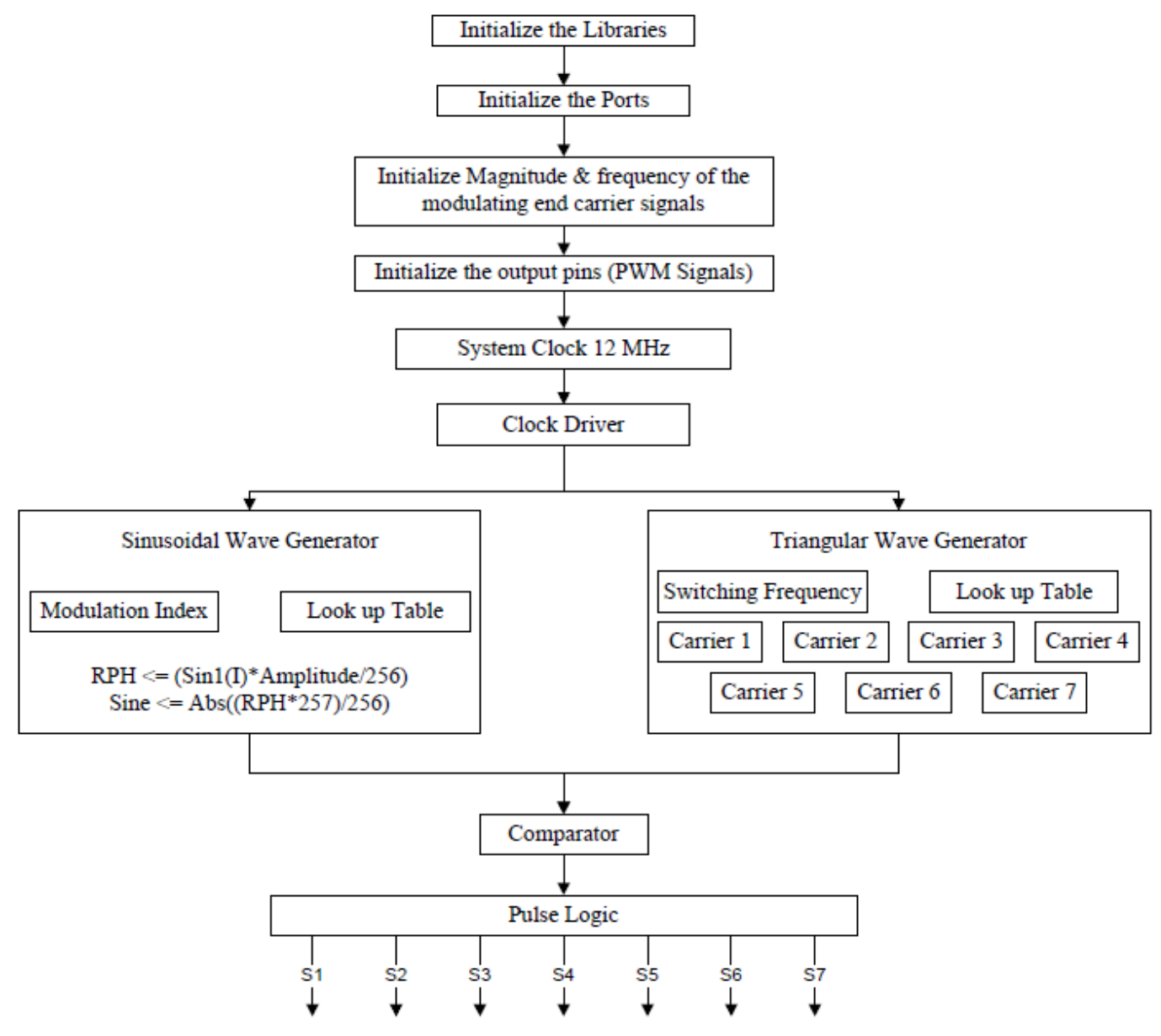

Figure 28. Flow chart for generating switching pulses for LG part using FPGA 


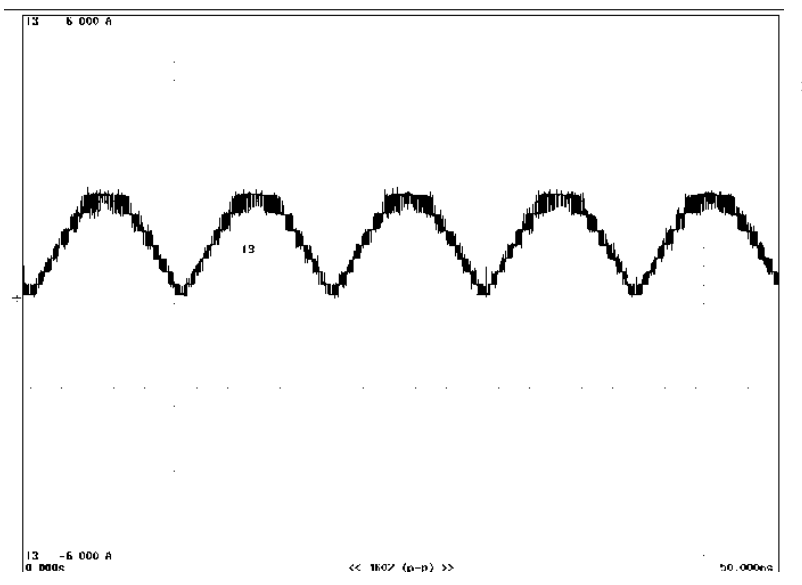

Figure 29. Out of level generation unit

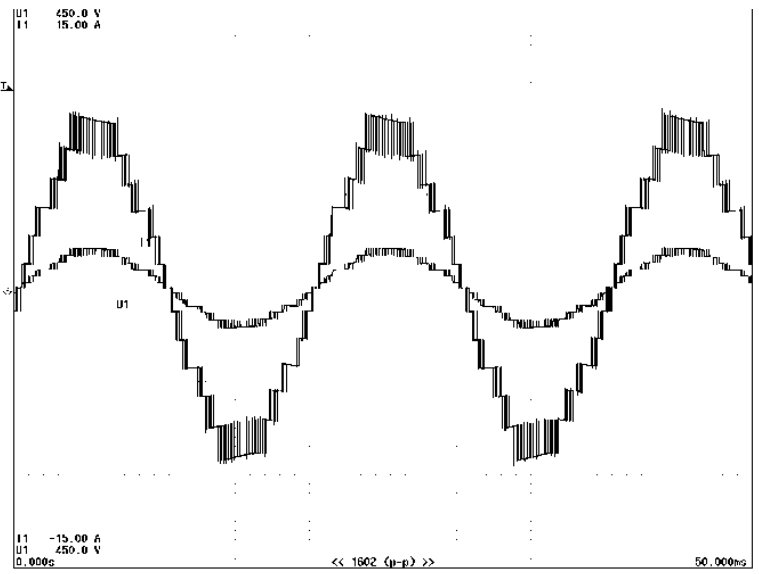

Figure 30. Output voltage and current for R load without filter

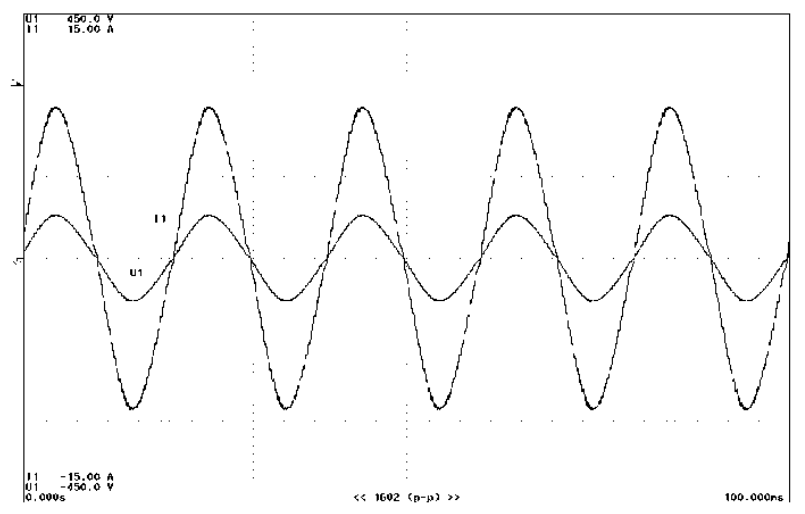

Figure 31. Output voltage and current for R Load with filter

Table 9. Comparison of \% THD for R Load

\begin{tabular}{|c|c|c|c|c|c|c|c|c|c|c|c|c|}
\hline MI & \multicolumn{4}{|c|}{ Switching frequency $=2 \mathrm{kHz}$} & \multicolumn{4}{|c|}{ Switching frequency $=5 \mathrm{kHz}$} & \multicolumn{4}{|c|}{ Switching frequency $=10 \mathrm{kHz}$} \\
\hline 1 & 4.58 & 2.02 & 4.67 & 2.06 & 3.05 & 1.15 & 3.01 & 1.63 & 5.02 & 4.05 & 5.04 & 4.05 \\
\hline 0.8 & 5.02 & 2.25 & 5.04 & 2.29 & 3.13 & 2.03 & 3.07 & 2.07 & 5.12 & 4.22 & 5.21 & 4.20 \\
\hline 0.6 & 5.80 & 2.65 & 5.90 & 2.67 & 3.79 & 2.22 & 3.79 & 2.27 & 5.98 & 4.54 & 5.97 & 4.52 \\
\hline
\end{tabular}

\section{CONCLUSION}

In this paper, a new inverter topology has been proposed which has superior features over conventional topologies in terms of the required power switches, control requirements, cost, and reliability. It is shown that this topology can be a good candidate for converters used in power applications such as FACTS, HVDC, PV systems, UPS, etc. In the discussed topology, the switching operation is separated into high- and low-frequency parts. This will add up to the efficiency of the converter as well as reducing the size and cost of the final prototype. The IPD-SPWM control method is used to drive the inverter. The simulation and experimental results of the topology for a fifteen-level inverter are shown in this paper. The results clearly show that the topology discussed can effectively work as a multilevel inverter with a reduced number of carriers for PWM and can be easily extendable to any required number of levels. 


\section{ACKNOWLEDGEMENTS}

Authors acknowledge the management of Shri Vishnu Engineering College for for their support in preparing theis paper.

\section{REFERENCES}

[1] L. M. Tolbert et al, "Multilevel converters for large electric drives," in Proc. IEEE APEC'98, vol. 2, 1998, pp. 530-536.

[2] Y. Chen, B. et al, "Regulating and equalizing dc capacitance voltages in multilevel statcom," IEEE Trans.Power Delivery, vol. 12, pp. 901-907, Apr. 1997.

[3] J.-S. Lai et al "Multilevel converters-A new breed of power converters," IEEE Trans. Ind. Applicat., vol. 32, pp. 509-517, May/June 1996.

[4] K. Jang-Hwan, S.-K. Sul, and P. N. Enjeti, "A carrier-based PWM method with optimal switching sequence for a multilevel four-leg voltagesource inverter," IEEE Trans. Ind. Appl., vol. 44, no. 4, pp. 1239-1248,Jul./Aug. 2008.

[5] S. Srikanthan et al, "DC capacitor voltage equalization in neutral clamped inverters for DSTATCOM application," IEEE Trans. Ind. Electron., vol. 57, no. 8, pp. 2768-2775, Aug. 2010.

[6] L. M. Tolbert, et al, "Multilevel converters for large electric drives," IEEE Trans. Ind. Appl., vol. 35, no. 1, pp. 3644, Jan./Feb. 1999.

[7] R. H. Osman, "A medium-voltage drive utilizing series-cell multilevel topology for outstanding power quality," in Conf. Rec. 34th IEEE IAS Annu. Meeting, 1999, vol. 4, pp. 2662-2669.

[8] E. Najafi et al, "A novel current mode controller for a static compensator utilizing Goertzel algorithm to mitigate voltage sags,"Energy Convers. Manage, vol. 52, no. 4, pp. 1999-2008, Apr. 2011.

[9] N. Seki and H. Uchino, "Converter conFigureurations and switching frequency for a GTO reactive power compensator,” IEEE Trans. Ind. Appl., vol. 33, no. 4, pp. 1011-1018, Jul./Aug. 1997.

[10] G. Shahgholiyan, et al, "Improving the mitigation of voltage flicker by usage of fuzzy control in a distribution static synchronous compensator (DSTATCOM)," Majlesi J. Elect. Eng., vol. 3, no. 2, pp. 25-35, Jun. 2009.

[11] K. Nakata, et al, "A three-level traction inverter with IGBTs for EMU," in Conf. Rec. IEEE IAS Annu. Meeting, 1994, vol. 1, pp. 667-672.

[12] A. Jidin, et al, "An optimized switching strategy for quick dynamic torque control in DTC-hysteresis-based induction machines," IEEE Trans. Ind. Electron., vol. 58, no. 8, pp. 3391-3400, Aug. 2011.

[13] K. Y. Lau, et al, "Performance analysis of hybrid photovoltaic/diesel energy system under Malaysian conditions," J. Energy, vol. 35, no. 8, pp. 3245-3255, Aug. 2010.

[14]. Ramkumar S, et al. "A new series parallel switched multilevel dc-link inverter topology", Int J Electr Power Energy Syst 2012; 36:93-9.

[15] G. Ceglia, et al, "A new simplified multilevel inverter topology for dc-ac conversion," IEEE Trans. Power Electron., vol. 21, no. 5, pp. 1311-1319, Sep. 2006.

[16] Nakul Thombre, et al, "A Novel Topology of Multilevel Inverter with Reduced Number of Switches and DC Sources", International Journal of Power Electronics and Drive System (IJPEDS), Vol. 5, No. 1, July 2014, pp. 56 62, ISSN: 2088-8694.

[17]. Tolbert, L. M.; et al. "Multilevel PWM methods at low modulation indices", Applied Power Electronics Conference and Exposition, 1999. APEC '99. Fourteenth Annual, Dallas, Texas. March 1999, pp. 1032-1039. ISBN 0-7803-5160-6.

[18]. Kim, J.-H et al "A carrier-based PWM method with optimal switching sequence for a multi-level four-leg VSI", Industry Applications Conference, 2005. Fourtieth IAS Annual Meeting. Conference Record of the 2005. June 2005, pp. 99-105. ISSN: 0197-2618. ISBN 0-7803-9208-6.

[19]. Tolbert, et al. "Novel multilevel inverter carrier-based PWM methods". Industry Applications Conference, 1998. Thirty- Third IAS Annual Meeting. The 1998 IEEE, Missouri. USA. October 1998, pp. 1424-1431. ISBN 0-78034943-1.

[20]. STEINKE, J. K. "Control strategy for a three phase AC tractiondrive with three-level GTO PWM inverter", Power Electronics Specialists Conference, PESC '88 Record., 19th Annual IEEE, Kyoto, Japan. 1988, pp. 431-438. DOI: 10.1109/PESC.1988.18164.

[21]. EHSAN NAJAFI, et al, "Design and implementation of a New Multi level Inverter Topology", IEEE transactions on Industrial Electronics ,Vol. 59, No. 11, November 2012 pp 4148-4154.

[22] K.S. Srikanth, "A Three Phase Multi Level Converter for grid Connected PV System”, International Journal of Power Electronics and Drive System (IJPEDS), Vol. 5, No. 1, July 2014, pp. 71 75, ISSN: 2088-8694

[23] S. G. Song, et al, "Cascaded multilevel inverter employing three-phase transformers and single dc input," IEEE Trans. Ind. Electron., vol. 56, no. 6, pp. 2005-2014, Jun. 2009.

[24] C Bharatiraja, et al, "FPGA based practical implementation of NPC-MLI with SVPWM for an autonomous operation PV system with capacitor balancing", International Journal of Electrical Power \& Energy Systems, 61 (2014) 489-509.

[25] Ul-Haq, "FPGA based one-cycle control of multilevel cascaded H Bridge inverter", in: proceedings of the 40th Annual Conference of the IEEE, IECON 2014, Industrial Electronics Society, 2014, PP. 46284634. 